\title{
Respon pertumbuhan cendawan patogenik Fusarium oxysporum terhadap metabolit sekunder cendawan antagonis Trichoderma sp.
}

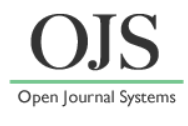

\author{
Tunjung Pamekas ${ }^{1 *}$, Usman Kris Joko Suharjo ${ }^{2}$, FitriA Andriyani ${ }^{3}$ \\ ${ }^{1}$ Program studi Proteksi Tanaman, Fakultas Pertanian, Universitas Bengkulu \\ ${ }^{2}$ Program studi Agroekoteknologi, Fakultas Pertanian, Universitas Bengkulu \\ ${ }^{3}$ Alumni Program studi Agroekoteknologi, Fakultas Pertanian, Universitas \\ *Email: tunjungpamekas@unib.ac.id
}

DOI: https://doi.org/10.33369/pendipa.4.3.75-81

\begin{abstract}
[Growth responses of pathogenic fungus Fusarium oxysporum to secondary metabolites of antagonistic fungi Trichoderma sp.] Fusarium oxysporum is a pathogenic fungus that attack various horticultural crops. Disease control using chemical pesticides have caused many negative effects to natural enemies, environment, famers, and consumers. It is needed to explore other alternative control methods. Application of secondary metabolite of Trichoderma sp. is a high potential control method to be used to control the disease. The aim of the research was to evaluate the best concentration of secondary metabolites on controlling F. oxysporum in vitro. The research was conducted on August to November 2017 at Plant Protection Laboratory, Faculty of Agriculture, University of Bengkulu. The research was arranged on CRD with six concentrations of secondary metabolites, namely 0, 10, 25, 50, 75 , and $100 \mathrm{ppm}$ with five replications. The research steps were isolation of $\mathrm{F}$. oxysporum and Trichoderma sp., production of secondary metabolites, in vitro test of secondary metabolites to $\mathrm{F}$. oxysporum, and analyse infrared photometer of secondary metabolites. Variables that were observed were colony diameter $1-7$ days, length and width of conidia, density of conidia, and length and width of germ tubes. The result showed that application of secondary metabolite gave significantly effect to all variables, except the germ tube width. The diameter colony of $\mathrm{F}$. oxysporum was inhibited $27.99-$ $35.43 \%$, the length and width of conidia were inhibited $49.63 \%$ and $49.06 \%$, the density of conidia was inhibited $75 \%$, and the length of germ tube was inhibited $62.47 \%$. The higher concentration of secondary metabolites the bigger the growth inhibition of F. oxysporum.
\end{abstract}

Keywords: Fusarium oxysporum, secondary metabolites, Trichoderma sp., in vitro, infrared photometer.

\begin{abstract}
ABSTRAK
Fusarium oxysporum merupakan cendawan patogenik pada berbagai tanaman hortikultura yang bisa menyebabkan gagal panen. Pengendalian patogen tersebut dengan aplikasi pestisida kimia sintetik telah menimbulkan berbagai dampak negatif terhadap musuh alami, lingkungan, petani, maupun konsumen. Oleh karena itu perlu dicari alternatif pengendalian yang lain. Aplikasi metabolit sekunder cendawan antagonis Trichoderma sp. sangat potensial sebagai salah satu metode pengendalian patogen tersebut. Tujuan dari penelitian adalah mengevaluasi konsentrasi metabolit sekunder Trichoderma sp. terbaik dalam menghambat pertumbuhan $F$. oxysporum secara in vitro. Penelitian dilaksanakan pada bulan Agustus - November 2017 di laboratorium Proteksi Tanaman, Fakultas Pertanian, Universitas Bengkulu. Penelitian disusun dalam Rancangan Acak Lengkap dengan faktor tunggal, yaitu konsentrasi metabolit sekunder Trichoderma sp. yang terdiri dari: 0, 10, 25, 50, 75, dan 100 ppm dengan lima ulangan. Tahapan penelitian meliputi: isolasi F. oxysporum, isolasi Trichoderma sp. produksi metabolit sekunder, pengujian metabolit sekunder Trichoderma sp. terhadap pertumbuhan $F$. oxysporum, dan analisis spektrofotometri infra merah metabolit sekunder Tricoderma sp. Variabel yang diamati adalah diameter koloni hari 1-7 hsi, panjang dan lebar konidia, kerapatan konidia, panjang dan lebar kecambah $F$. oxysporum. Hasil penelitian menunjukkan bahwa semua variabel pertumbuhan $F$. oxysporum dipengaruhi secara sangat nyata oleh adanya metabolit sekunder Trichoderma sp, kecuali variabel lebar kecambah. Pertumbuhan diameter koloni $F$. oxusporum terhambat $27,99-35,43 \%$, panjang dan lebar
\end{abstract}


konidia terhambat 49,63 dan 49,06\%, kerapatan konidia terhambat $75 \%$, dan panjang kecambah terhambat $62,47 \%$. Semakin tinggi konsentrasi metabolit sekunder Trichoderma sp yang diberikan maka semakin besar penghambatan pertumbuhan.

Kata kunci: Fusarium oxysporum, metabolit sekunder, Trichoderma sp., in vitro, fotometer infra merah.

\section{PENDAHULUAN}

Cendawan patogen Fusarium oxysporum dapat menyerang berbagai tanaman hortikultura, diantaranya famili solanaceae seperti tomat, kentang, dan terung (Latifah, 2011). Patogen menginfeksi akar muda tanaman dan berkembang sampai ke jaringan pengangkut dari akar hingga ke batang dan menyumbat jaringan pengangkut sehingga pasokan air ke daun terhambat. Gejala layu muncul pada pucuk tanaman dan terus berlangsung ke batang hingga akhirnya tanaman layu dan mati (Soesanto et al., 2013). Freeman et al. (2002) menyatakan bahwa serangan $F$. oxysporum menjadi salah satu pembatas yang menyebabkan terjadinya penurunan produksi kentang.

Pada umumnya pengendalian penyakit layu tersebut dilakukan dengan menggunakan pestisida kimia sintetik. Namun dengan banyaknya dampak negatif dari penggunaan pestisida kimia sintetik, seperti matinya musuh alami, resistensi, resurgensi, pencemaran lingkungan, dan keracunan petani maupun konsumen maka perlu dicari metode pengendalian lain yang murah, efektif, dan aman. Pengendalian hayati dengan metabolit sekunder cendawan antagonis Trichoderma sp. merupakan satu alternatif pengendalian yang perlu diteliti. Trichoderma sp. berperan penting dalam menekan pertumbuhan patogen tanaman, terutama cendawan tular tanah (Mukarlina et al., 2010). Kope dan Fortin (1990) melaporkan bahwa metabolit sekunder cendawan antagonis dapat melisis hifa dan konidia serta menghambat germinasi spora berbagai cendawan patogen. Andriansyah et al (2015) melaporkan metabolit sekunder Trichoderma sp. dapat menghambat pertumbuhan Pseudomonas solanacearum hingga 35,98\%. Mukherjee et al. (2012) melaporkan bahwa Trichoderma sp. menghasilan enzim, antibiotik, dan toksin yang mampu menekan pertumbuhan pathogen.

Tujuan dari penelitian adalah untuk mengevaluasi konsentrasi metabolit sekunder
Trichoderma sp. isolat lokal Bengkulu dalam menghambat pertumbuhan Fusarium oxysporum in vitro.

\section{METODE PENELITIAN}

Waktu dan Lokasi Penelitian

Penelitian dilaksanakan pada bulan Agustus samai dengan November 2017 bertempat di Laboratorium Proteksi Tanaman, Fakultas Pertanian, Universitas Bengkulu.

\section{Rancangan Penelitian}

Penelitian disusun dalam Rancangan Acak Lengkap dengan faktor tunggal, yaitu konsentrasi metabolit sekunder Trichoderma sp. yang terdiri dari 6 konsentrasi: 0, 10, 25, 50, 75, dan $100 \mathrm{ppm}$. Setiap perlakuan diulang sebanyak 5 kali.

\section{Tahapan Penelitian}

Tahapan penelitian adalah isolasi dan identifikasi $F$. oxysporum, isolasi dan identifikasi Trichoderma sp., produksi metabolit sekunder Trichoderma sp. pengujian konsentrasi metabolit sekunder Trichoderma sp terhadap pertumbuhan $F$. oxysporum in vitro, dan analisis fotometer infra merah metabolit sekunder Trichoderma sp.

Isolasi $F$. oxysporum dilakukan dengan metode penanaman jaringan dengan mengambil sampel tanaman kentang yang terserang penyakit layu fusarium, sedangkan Trichoderma sp. diisolasi dengan metode pengenceran dengan sampel tanah perakaran tanaman kentang sehat.

Produksi metabolit sekunder Trichoderma sp. dilakukan dengen metode Dixon dan Gonzales (1994) yang dimodifikasi. Sebanyak 50 cakram koloni Trichoderma sp. ukuran 7 mm dimasukkan dalam $250 \mathrm{ml}$ medium PDB. Selanjutnya medium digoyang dengan saker 90 rpm pada suhu kamar $22^{\circ} \mathrm{C}$ dengan cahaya rendah selama 2 minggu. Kemudian medium PDB tersebut disubkultur dengan cara dibadi dua dan ditambahkan medium PDB baru hingga 
volume $250 \mathrm{ml}$. Selanjutnya medium digoyang lagi dengan cara yang sama selama 2 minggu. Medium PDB disentrifuse dengan kecepatan $1000 \mathrm{rpm}$ selama 5 menit. Supernatan diambil dengan menggunakan pipet mikro.

Pengujian konsentrasi metabolit sekunder Trichoderma sp. terhadap pertumbuhan $F$. oxysporum dilakukan 2 macam. Pertama, metabolit sekunder Trichoderma sp. sesuai konsentrasi ditambahkan ke dalam medium Potato Dextrose Agar (PDA) dalam cawan petri. Biakan murni $F$. oxusporum umur 4 hari dengan ukuran $7 \mathrm{~mm}$ diletakkan di tengah medium PDA. Selanjutnya medium diinkubasi pada suhu kamar. Variabel yang diamati adalah: diameter koloni diukur tiap hari sampai 7 hari, jumlah konidia, panjang konidia, dan kerapatan konidia yang diukur pada hari ke 7 . Kedua, metabolit sekunder Trichoderma sp. sesuai konsentrasi diteteskan di atas gelas objek yang telah berisi suspensi konidia $F$. oxysporum. Selanjutnya gelas objek ditutup dengan gelas penutup dan diinkubasi di dalam cawan petri berdiameter $18 \mathrm{~cm}$ selama 8 jam. Variabel yang diamati adalah panjang dan lebar kecambah $F$. oxysporum yang diukur dengan mikrometer di bawah mikroskop.

Kandungan senyawa kimia dalam metabolit sekunder Trichoderma sp. diamati secara kualitatif dengan analisis fotometer infra merah dengan panjang gelombang 500-4000. Analisis dilakukan di Laboratorium Kimia, FMIPA, Universitas Bengkulu.

\section{Analisis Data}

Data yang diperoleh dianalisis secara statistik dengan ANAVA taraf 5\% dan jika diperoleh hasil yang berbeda nyata atau sangat nyata dilanjutkan dengan uji Duncan Multiple Range Test (DMRT) pada taraf 5\%.

\section{HASIL DAN PEMBAHASAN}

Cendawan patogen $F$. oxysporum hasil isolasi menunjukkan pertumbuhan koloni dengan bentuk melingkar dan menyebar ke segala arah secara simetris. Koloni berwarna putih dan dalam waktu 4 hari diameter koloni mencapai 4-4,8 cm (Gambar 1a). Hasil pengamatan sesuai dengan pendapat Domcsh et al. (1980) bahwa koloni $F$. oxysporum berwarna putih dan diameter koloni dalam 4 hari berkisar $4,5-6,5 \mathrm{~cm}$.

Miselium $F$. oxysporum hialin dan bersepta. Makrokonidia berbentuk seperti bulan sabit dengan 3-5 sekat, sedangkan makrokonidia berbentuk bulat telur, lurus atau bengkok dan septa (Gambar 1b). Semangun (2001) melaporkan bahwa $F$. oxysporum memiliki miselium bersekat dan bercabang. Makrokonidia lurus atau bengkok seperti bulan sabit, dengan 3-5 sekat, dan berukuran 25-33 x 3,5-5,5 $\mu \mathrm{m}$. Mikrokonidia berbentuk bulat telur atau lurus, tidak bersekat atau bersekat satu, ukuran 6-15 x 2,5-4 $\mu \mathrm{m}$.
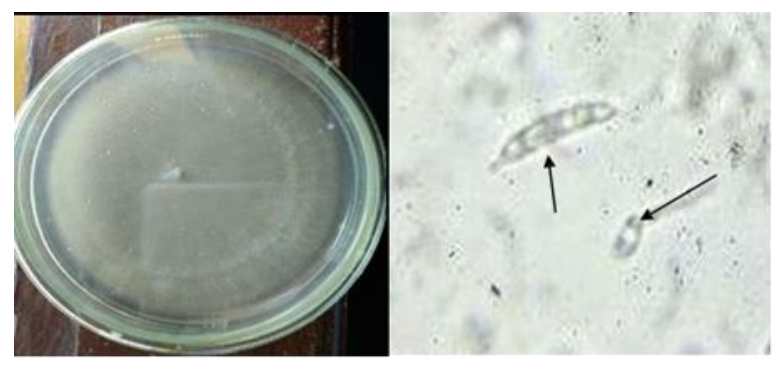

Gambar 1. Koloni, makrokonidia, dan mikrokonidia cendawan $F$. oxysporum

Cendawan Trichoderma sp. memiliki bentuk koloni yang melingkar konsentris dengan warna putih pada awal pertumbuhan dan berubah menjadi hijau. Diameter koloni mencapai 7-8 $\mathrm{cm}$ dalam waktu 4 hari (Gambar 2a). Domcsh et al. (1980) menyatakan bahwa pada umumnya koloni Trichoderma sp. dalam biakan tumbuh dengan cepat dengan warna putih sampai hijau.

Trichoderma sp. memiliki konidia berbentuk bulat dengan warna hijau yang dibentuk diujung konidiofor (Gambar 2b). Semangun (2001) melaporkan bahwa Trichoderma sp. mempunyai hifa bercabang dengan dinding licin dan tidak berwarna. Di ujung konidiofor terdapat konidia berbentuk bulat berukuran $2,8-3,2 \mu \mathrm{m}$.

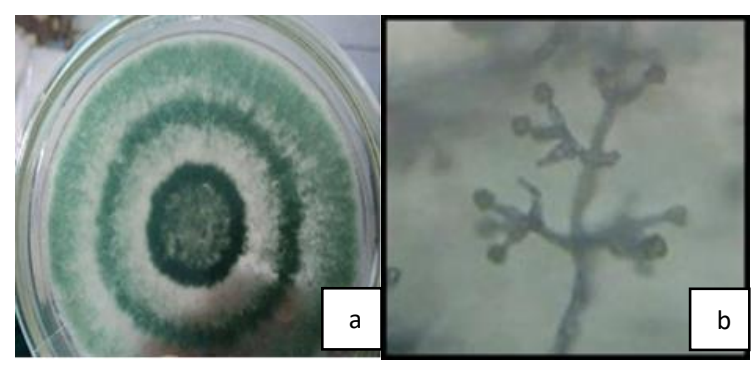

Gambar 2. Koloni dan konidia cendawan Trichoderma sp.

Dari Gambar 3 terlihat bahwa medium 
PDB plus cendawan Trichoderma umur 1 hari berbentuk cair dan warna orange jernih. Setelah digoyang dengan shaker selama 2 minggu medium PDB plus cendawan Trichoderma menjadi cair kepekatan dan berwarna merah bata kecoklatan. Warna merah bata kecoklatan menandakan adanya perkembangan cendawan Trichoderma dalam medium PDB. Kultur filtrat Trichoderma sp. yang mengandung metabolit sekunder berwarna kuning transparan (Gambar 3a-c).

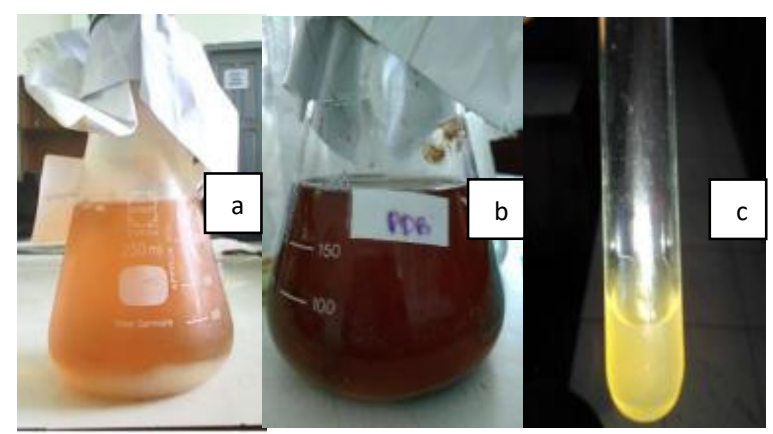

Gambar 3. Produksi metabolit sekunder cendawan Trichoderma sp.

Pemberian metabolit sekunder Trichoderma sp. berpengaruh nyata atau sangat nyata terhadap perkembangan diameter koloni, panjang dan lebar konidia, kerapatan konidia, dan panjang kecambah cendawan $F$. oxysporum (Tabel 1-2). Pertumbuhan diameter koloni cendawan $F$. oxysporum semakin terhambat seiring dengan meningkatnya konsentrasi metabolit sekunder Trichoderma sp. (Gambar 4). Penghambatan metabolit sekunder Trichoderma sp. terhadap diameter koloni $F$. oxysporum berkisar 27,99 -35,43\%.

Hal yang sama terlihar pada variabel panjang dan lebar konidia, kerapatan konidia, dan panjang kecambah $F$. oxysporum (Tabel 2).
Metabolit sekunder Trichoderma sp. menyebabkan $F$. oxysporum memiliki panjang dan lebar konidia yang lebih pendek, kerapatan konidia yang lebih sedikit, dan panjang kecambah yang lebih pendek. Penghambatan metabolit sekunder Trichoderma sp. terhadap panjang konidia, lebar konidia, kerapatan konidia, dan panjang kecambah $F$. oxysporum berturut-turut 49,$63 ; 49,06 ; 75$, dan $62,47 \%$.

Perkembangan diameter koloni, panjang konidia, lebar konidia, kerapatan konidia dan panjang kecambah cendawan $F$. oxysporum memiliki nilai yang semakin kecil seiring dengan semakin tingginya konsentrasi metabolit sekunder Trichoderma sp. yang diberikan. Hal ini menunjukkan bahwa metabolit sekunder Trichoderma sp. mampu menghambat laju perkembangan cendawan $F$. oxysporum, baik pada fase vegetatif maupun generatif.

El-Katatny et al. (2000) menyatakan bahwa Trichoderma sp. menghasilkan senyawa beracun yang dapat digunakan untuk mengendalikan pertumbuhan patogen serta penggunaan filtrat Trichoderma sp. yang mengandung enzim kitinase dan $\beta-1,3-$ glukanase mampu menekan pertumbuhan patogen. Enzim kitinase dari Trichoderma sp. lebih efektif daripada enzim kitinase yang diproduksi organisme lain dalam menghambat beberapa pathogen tanaman (Nugroho et al., 2003). Cherif dan Behamau (1990) mengatakan bahwa senyawa metabolit sekunder yang terkandung dalam kultur filtrat Trichoderma sp. dapat mendegradasi dinding sel cendawan sasaran yang mengakibatkan terganggunya pertumbuhan cendawan tersebut. Lebih lanjut Odebode (2006) melaporkan bahwa kultur filtrat Trichoderma sp. dapat menghambat cendawan Fusarium penyebab busuk buah pasca panen hingga mencapai $23,2 \%$. 
Tabel 1. Pengaruhh konsentrasi metabolit sekunder pada perkembangan diameter koloni cendawan

\begin{tabular}{|c|c|c|c|c|c|c|c|}
\hline $\begin{array}{c}\text { Konsentrasi metabolit } \\
\text { sekunder (ppm) }\end{array}$ & \multicolumn{7}{|c|}{\begin{tabular}{c} 
Diameter koloni cendawan \\
\hline
\end{tabular}} \\
\hline & 1 & 2 & 3 & 4 & 5 & 6 & 7 \\
\hline 0 & $11,4 \mathrm{a}$ & $23,6 \mathrm{a}$ & $35,0 \mathrm{a}$ & $44,6 \mathrm{a}$ & $53,6 \mathrm{a}$ & $66,6 \mathrm{a}$ & $80,0 \mathrm{a}$ \\
\hline 25 & $10,6 \mathrm{ab}$ & $22,6 \mathrm{a}$ & $32,0 \mathrm{ab}$ & $41,2 \mathrm{a}$ & $52,6 \mathrm{ab}$ & $66,6 \mathrm{a}$ & $76,0 \mathrm{~b}$ \\
\hline 50 & $10,6 \mathrm{ab}$ & $23,0 \mathrm{a}$ & $31,4 \mathrm{ab}$ & $42,4 \mathrm{a}$ & $52,0 \mathrm{ab}$ & $65,0 \mathrm{a}$ & $76,4 \mathrm{~b}$ \\
\hline 75 & $9,8 \mathrm{bc}$ & $19,8 \mathrm{~b}$ & $30,6 \mathrm{~b}$ & $42,6 \mathrm{a}$ & $52,8 \mathrm{ab}$ & $63,8 \mathrm{a}$ & $74,4 \mathrm{~b}$ \\
\hline 100 & $9,0 \mathrm{~cd}$ & $17,8 \mathrm{bc}$ & $29,0 \mathrm{~b}$ & $40,8 \mathrm{a}$ & $48,4 \mathrm{~b}$ & $56,8 \mathrm{~b}$ & $69,6 \mathrm{c}$ \\
\hline & $8,0 \mathrm{~d}$ & $15,8 \mathrm{c}$ & $22,6 \mathrm{c}$ & $31,0 \mathrm{~b}$ & $38,6 \mathrm{c}$ & $47,0 \mathrm{c}$ & $55,0 \mathrm{~d}$ \\
\hline
\end{tabular}

Ket: Angka-angka yang diikuti oleh huruf yang berbeda pada kolom yang sama berarti berbeda nyata pada uji DMRT taraf 5\%

Tabel 2. Pengaruh konsentrasi metabolit sekunder terhadap panjang, lebar dan kerapatan konidia serta panjang dan lebar kecambah cendawan F.oxysporum

\begin{tabular}{|c|c|c|c|c|c|}
\hline $\begin{array}{c}\text { Konsentrasi } \\
\text { metabolit } \\
\text { sekunder }(\mathbf{p p m})\end{array}$ & $\begin{array}{c}\text { Panjang } \\
\text { konidia } \\
(\boldsymbol{\mu m})\end{array}$ & $\begin{array}{c}\text { Lebar } \\
\text { konidia } \\
(\boldsymbol{\mu m})\end{array}$ & $\begin{array}{c}\text { Kerapata } \\
\mathbf{n ~ k o n i d i a} \\
(\mathbf{1 0} / \mathbf{m l})\end{array}$ & $\begin{array}{c}\text { Panjang } \\
\text { kecambah } \\
(\boldsymbol{\mu m})\end{array}$ & $\begin{array}{c}\text { Lebar } \\
\text { kecambah } \\
(\boldsymbol{\mu m})\end{array}$ \\
\hline 0 & $40,5 \mathrm{a}$ & $10,6 \mathrm{a}$ & $2,4 \mathrm{a}$ & $78,6 \mathrm{a}$ & 11,2 \\
\hline 10 & $35,2 \mathrm{~b}$ & $8,7 \mathrm{~b}$ & $2,0 \mathrm{~b}$ & $74,2 \mathrm{a}$ & 11,4 \\
\hline 25 & $30,8 \mathrm{c}$ & $7,2 \mathrm{c}$ & $1,9 \mathrm{~b}$ & $63,7 \mathrm{a}$ & 11,1 \\
\hline 50 & $28,3 \mathrm{~d}$ & $6,9 \mathrm{c}$ & $1,5 \mathrm{c}$ & $41,1 \mathrm{~b}$ & 10,6 \\
\hline 75 & $26,6 \mathrm{~d}$ & $6,5 \mathrm{~cd}$ & $0,9 \mathrm{~d}$ & $40,0 \mathrm{~b}$ & 10,4 \\
\hline 100 & $20,4 \mathrm{c}$ & $5,4 \mathrm{~d}$ & $0,6 \mathrm{~d}$ & $29,5 \mathrm{~b}$ & 10,0 \\
\hline
\end{tabular}

Ket: Angka-angka yang diikuti oleh huruf yang berbeda pada kolom yang sama berarti berbeda nyata pada uji DMRT taraf $5 \%$
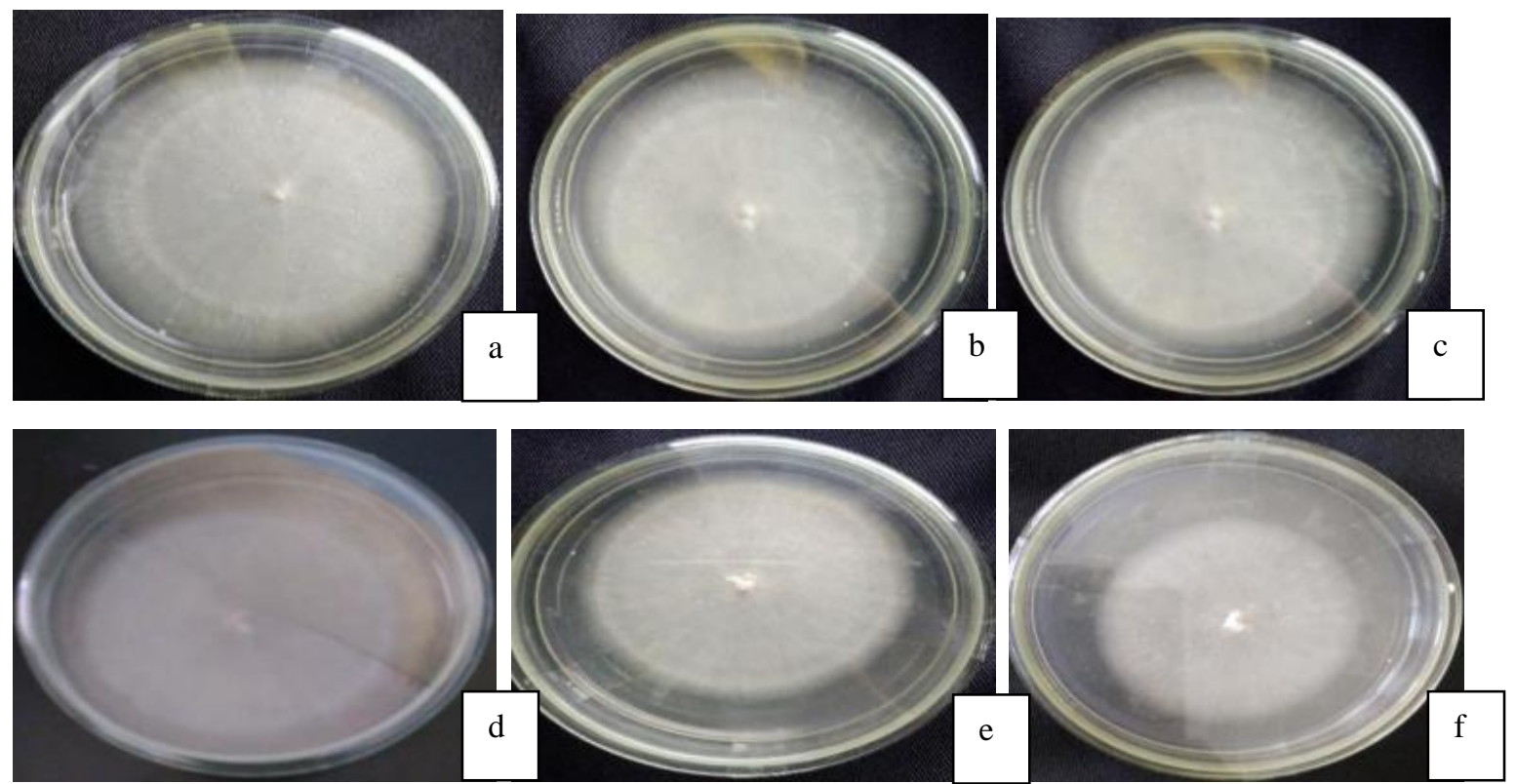

Gambar 4. Pengaruh konsentrasi metabolit sekunder Trichoderma sp. terhadap diameter koloni cendawan $F$. oxysporum padahari ke-7 
Hasil spektra fotometer infra merah dari metabolit sekunder Trichoderma sp. menunjukkan bahwa metabolit sekunder

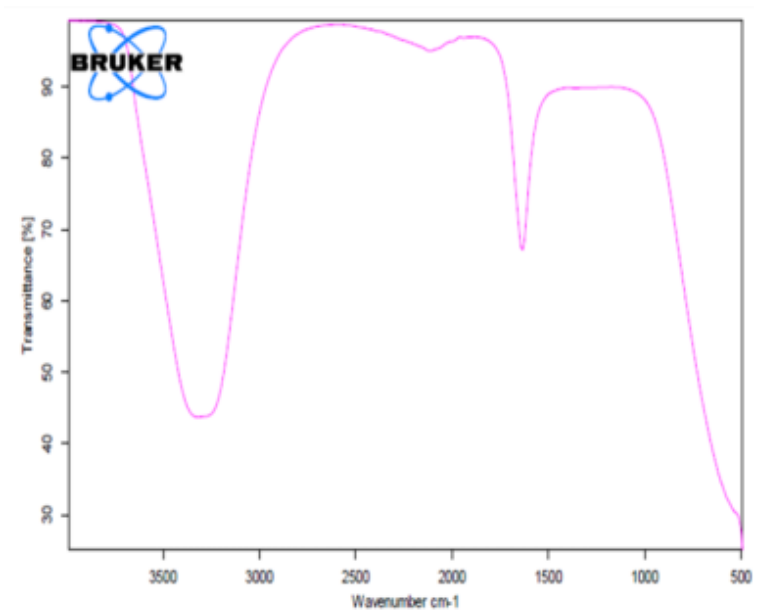

Gambar 5. Spektra fotometer infra merah dari metabolit sekunder cendawan Trichoderma sp.

tersebut mengandung 6 jenis senyawa kimia yang berbeda dengan panjang gelombang 5004000 (Gambar 4). Keenam jenis senyawa kimia tersebut berperan penting dalam proses penghambatan pertumbuhan cendawan $F$. oxysporum.

Dari spektra infra merah tersebut belum dapat diidentifikasi jenis senyawa kimianya, sehingga perlu diidentifikasi lebih lanjut dengan analisis HPLC. Namun beberapa hasil penelitian telah melaporkan bahwa metabolit sekunder Trichoderma sp. mengandung enzim kitinase dan $\beta$-1,3-glukanase (El-Katany et al., 2000), toksin harzianic acid, tricholin, peptaibols, gliotoxin, viridian, T22azaphinlone, 1 hydroxy-3-methyl-anthraquinone, 1,8dihydroxy-3-methyl-anthraquinone,

T39butenolide, harzianolide, dan harzianopyridone (Mukherjee et al., 2012).

\section{KESIMPULAN}

Dari penelitian yang sudah dilakukan, kesimpulan yang bisa diambil adalah sbb.:

1. Konsentrasi metabolit sekunder cendawan Trichoderma sp. 100 ppm paling baik dalam menghambat perkembangan diameter koloni, panjang dan lebar konidia, kerapatan konidia, serta panjang kecambah cendawan $F$. oxysporum.

2. Metabolit sekunder cendawan Trichoderma sp. mengandung 6 jenis senyawa kimia.

\section{DAFTAR PUSTAKA}

Andriansyah, Agung. Meydina Arri S. Mahmudah Namawi, Ali Ikhwan. (2015) Uji Metabolit Sekunder Trichoderma sp. sebagai Antimikrobia Patogen Tanaman Pseudomonas solanacearum secara In Vitro, Gontor AGROTECH Science Journal, 2 (1), 25-27.

Cherif, M. dan Benhamou N. (1990). Cytochemical Aspects of Chitin Breakdown During the Paracitic Action of a Trichoderma sp. On Fusarium oxysporum spp. Radices Lychopersia, Phytophatology, 80,1406-1414.

Dixon, RA and RA Gonzales. 1994. Plant cell culture. Oxford Univ. Press. England. $450 \mathrm{p}$.

Domsch, K.H. 1980. Compendium of Soil Fungi. Academics Press. London.

El-Katatny, M. H., Somitsch W.,Roba K. H., Gubitz. ( 2000) Production of citinase and $\beta$-1, 3-glucanase by $T$. harzianum. Food Technol Biocontrol.,38 (3),178-180.

Freeman, S. A. Zveibil. H. Vintal, M. Maymo. (2002) Isolation of nonpathogenic mutants of Fusarium oxysporum f. sp. melonis for biological control of Fusarium wilt in cucurbits. Phytopathology, 92, 164-168.

Kope, HH and JA Fortin. 1990. Antifungal activity in culture filtrate of the actomycorrhized fungus Pisolithus tinctorius. Can. J. of Botany, 68(6),12541259.

Latifah, A. Kustantinah dan L. Soesanto. 2011. Pemanfaatan beberapa isolat Trichoderma harzianum sebagai agensia pengendali hayati penyakit layu Fusarium pada bawang merah. Plant Eugenia, 17. 2.

Mukarlina, S. Khotimah dan R. Rianti. 2010. Uji antagonis Trichoderma harzianum terhadap Fusarium spp. penyebab penyakit layu pada tanaman cabai (Capsicum annum) secara Ii vitro. Jurnal Fitomedika, 7(2), 80-85.

Mukherjee, P. K., Harwitz dan Kenely. 2012. Secondary metabolism in Trichoderma. A Genomic Perspective Microbial, 158, 3545.

Nugroho, T.T. Ali. M. Ginting, C. 
Wahyuningsih. Dahliaty. A. Devi. S. Sukmarisa. 2003. Isolasi dan Karakterisasi Sebagian Kitinase Trichoderma Viride. Natur Indonesia. 5. 101-106.

Odebode, A. C. 2006. Control of postharvest pathogens of fruits by cultur filtrate from antagonistic fungi. Jurnal of Plant Protection Research, 46(1), 45-56.
Semangun, H. 2001. Pengantar Ilmu Penyakit Tumbuhan. Gajah MAda University Press. Yogyakarta

Soesanto, L.E. Mugiastuti1. R.F. Rahayuniati1 dan R. S. dewi. 2013. Uji kesesuaian empat isolat Trichoderma spp. dan daya hambat in vitro terhadap beberapa patogen tanaman. Jurnal Hpt tropika,13(2), 117123. 